\section{Trinexapac-ethyl Increases Kentucky Bluegrass Leaf Cell Density and Chlorophyll Concentration}

\author{
E.H. Ervin ${ }^{1}$ and A.J. Koski ${ }^{2}$ \\ Department of Horticulture and Landscape Architecture, Colorado State \\ University, Fort Collins, CO 80523
}

Additional index words. turfgrass, plant growth retardant, anti-gibberellin, Poa pratensis

\begin{abstract}
The effects of trinexapac-ethyl (TE) on the anatomical and biochemical composition of turfgrasses and their implications for its field use are poorly understood. Two greenhouse experiments were conducted to determine if application of TE increased Kentucky bluegrass (Poa pratensis L.) leaf blade cell density, chlorophyll concentration, or structural carbohydrate content. Kentucky bluegrass (KB) sod was harvested from the field, established in greenhouse pots, and sprayed with $0.27 \mathrm{~kg} \cdot \mathrm{ha}^{-1} \mathrm{a}$.i. TE. Leaf blade samples were collected 4 weeks after treatment (WAT), fixed in glutaraldehyde, and embedded in Spurr resin. Photomicrographs of longitudinal leaf blade sections were used to determine cell density, cell length, and cell width. Chlorophyll and structural carbohydrate contents were determined at 2 and 4 WAT. Treatment with TE increased cell density and chlorophyll-b concentration, while reducing cell length, but structural carbohydrate content was unaffected. Chemical name used: 4-cyclopropyl- $\alpha$-hydroxy-methylene-3,5dioxo-cyclohexanecarboxylic acid ethyl ester (trinexapac-ethyl).
\end{abstract}

Trinexapac-ethyl (TE) is a growth retardant commonly used on turfgrass that effectively reduces cool- and warm-season grass leaf growth and subsequent mowing requirement (Ervin and Koski, 1998, 2001; Fagerness and Penner, 1998; Johnson, 1993, 1994). The chemical competitively inhibits the conversion of $\mathrm{GA}_{20}$ to $\mathrm{GA}_{1}$ by 3-ß-hydroxylase, markedly reducing leaf cell elongation (Adams et al., 1992) but not cell division. The cell division involved in initiation and growth of new tillers from axillary meristems (Esau, 1953) appears to be promoted by TE. Increases in turfgrass tiller density following TE applications have been reported in perennial ryegrass (Lolium perenne $\mathrm{L}$.) and Kentucky bluegrass (Poa pratensis L.) (KB) (Ervin and Koski, 1998, 2001). Increased cytokinin levels in plants treated with inhibitors of gibberellin biosynthesis (Grossmann, 1991) may be responsible for increasing tiller density and chlorophyll concentration, while delaying senescence.

We know of no published reports concerning the specific effects of TE on leaf cell anatomy. However, a study involving two nearly isogenic genotypes of winter wheat (Triticum aestivum L.) - a semidwarf containing 'Norin 10' anti-gibberellin genes and

\footnotetext{
Received for publication 22 May 2000. Accepted for publication 28 Sept. 2000. We thank Kimberly V. Davidson for technical assistance. This research was supported by the Colorado State Univ. Agricultural Experiment Station. The cost of publishing this paper was defrayed in part by the payment of page charges. Under postal regulations, this paper therefore must be hereby marked advertisement solely to indicate this fact.

${ }^{1}$ Assistant Professor. E-mail address: ErvinE@ missouri.edu

${ }^{2}$ Associate Professor.
}

experiments reported herein were conducted with the objectives of determining if application of TE to KB increases cell density, chlorophyll concentration, and structural carbohydrate content of leaves.

\section{Materials and Methods}

The data reported are from two separate experiments. In the first, greenhouse-maintained pots of 'NuStar' KB were used to provide samples for determination of TE effects on mesophyll cell density and leaf blade chlorophyll concentration. In the second experiment, large flats of 'NuStar' KB were used to provide samples for determination of structural carbohydrate content using the neutral detergent fiber test.

Expt. 1. Effects of TE on cell density and chlorophyll concentration. 'NuStar' KB plants were grown in $12.7-\mathrm{cm}$-diameter $\times 12.7-\mathrm{cm}$ deep pots arranged in five randomized complete blocks $(n=10)$ in a fiberglass-reinforced, plastic-covered greenhouse. The pots were filled with a Nunn clay loam (fine montmorillonitic mesic Aridic Argiustoll, $\mathrm{pH}=7.8$ ) from the field and 12.7-cm-diameter sod pieces were planted in the pots on 20 Mar. 1997. The plants were watered every $2 \mathrm{~d}$ and mowed once weekly with electric shears to $6.4 \mathrm{~cm}$. Plants received fertigation once per week, which provided $\left(\mathrm{mg} \cdot \mathrm{L}^{-1}\right) 200 \mathrm{~N}$ (urea), $29 \mathrm{P}$, $166 \mathrm{~K}, 67 \mathrm{Ca}, 27 \mathrm{Mg}$, plus trace amounts of Fe, $\mathrm{B}, \mathrm{Cu}, \mathrm{Mn}, \mathrm{Mo}$, and $\mathrm{Zn}$. Greenhouse temperatures were $21 \pm 3^{\circ} \mathrm{C}$ day and $15.5 \pm 3^{\circ} \mathrm{C}$ night. Mean photosynthetic photon flux at $1300 \mathrm{HR}$, as measured by a LI-1000 datalogger with a LI-190SA quantum sensor (LI-COR, Lincoln, Nebr.), was 830 and $1800 \mu \mathrm{mol} \cdot \mathrm{m}^{-2} \cdot \mathrm{s}^{-1}$ in the greenhouse and in full sun, respectively. Thus, incident photosynthetically active radiation in the greenhouse was $\approx 46 \%$ of that in full sun. The foliage in half of the pots was sprayed with TE on 26 Sept. 1997, using a hand-held pump sprayer to deliver $0.27 \mathrm{~kg} \cdot \mathrm{ha}^{-1}$ a.i. TE at a pressure of $207 \mathrm{kPa}$ and application volume of $0.1 \mathrm{~L} \cdot \mathrm{m}^{-2}$.

Plant microtechnique for cell density determination. Four weeks after treatment (WAT) (23 Oct. 1997), the most recently expanded leaf blades were harvested and prepared for light microscopy. Twenty sections, 1 mm wide, were immediately cut from the blade $\approx 10 \mathrm{~mm}$ from the ligule. This sample region was chosen because it has been reported to be the site of maximum cell elongation in tall fescue, and is also within the reported zones of cell division ( 0 to $15 \mathrm{~mm}$ from the leaf blade base) and cell elongation ( 0 to 30 $\mathrm{mm}$ from the leaf blade base) of tall fescue (MacAdam et al., 1989; Schnyder and Nelson, 1988). Preparation of the leaf samples for light microscopy followed standard procedures (Berlyn and Miksche, 1976) of fixation with $3 \%$ glutaraldehyde, post-fixation in $1 \%$ osmium tetroxide, dehydration in a graded series of ethanol solutions, and an infiltration and embedding series with ethanol and Spurr resin (Spurr, 1969; Electron Microscopy Services, Fort Washington, Pa.). Leaf sections $0.5 \mu \mathrm{m}$ thick were cut longitudinally with a glass mi- 
crotome and placed on slides. The sections were stained with $0.5 \%$ toluidine blue in $1 \%$ borax and a cover slip was attached with permount.

Four replicates per treatment (TE and control) were viewed under a light microscope and three sections per replicate were photographed with Ektachrome 160-Tungsten color film (Eastman Kodak Co., Rochester, N.Y.) at $\times 100$ magnification. At this magnification, mesophyll cells filled the entire photographed area of $\approx 14,000 \mu^{2}$. The photomicrographs were used to count the number of mesophyll cells within this area, and analysis of variance (ANOVA) (MSTAT, 1988) was used to analyze the results. Slides of the photomicrographs were scanned (Sprint Scan 35 Plus; Polaroid Corp., Cambridge, Mass.) and imported into WordPerfect (Corel, Orem, Utah). All images were set at the same proportions and hard copies were printed. A ruler (calibrated for converting $\mathrm{mm}$ to $\mu \mathrm{m}$ ) was used to measure cell lengths and widths directly from these printed images. Seven randomly chosen cells per photographed section were measured, and the average values were used in a one-way ANOVA to determine the possible treatment effects on cell length and width.

Chlorophyll extraction and concentration determination. On 23 Oct. 1997, TE (0.27 $\mathrm{kg} \cdot \mathrm{ha}^{-1}$ a.i.) was again applied to half of the $\mathrm{KB}$ pots in the greenhouse. At 2 WAT (6 Nov.) and again at 4 WAT (20 Nov.), $100 \mathrm{mg}$ of expanded leaf blade tissue was harvested from each of the pots, cut with a sterilized razor blade into small $(<1 \mathrm{~mm})$ pieces and placed in a test tube containing $5 \mathrm{~mL}$ dimethyl sulfoxide (DMSO) (Hiscox and Israelstam, 1979). The tubes were placed in a $65^{\circ} \mathrm{C}$ water bath for $4 \mathrm{~h}$ (Kane and Smiley, 1983). Once cool, $1 \mathrm{~mL}$ of the supernatant was placed in a cuvette and its absorbance at 645 and $663 \mathrm{~nm}$ was measured with a spectrophotometer (Beckman DU-640; Beckman Instruments, Fullerton, Calif.). Chlorophyll concentration (mg. $\mathrm{g}^{-1}$ fresh weight) was calculated using the equations of Arnon (1949). Data from two 100 -mg subsamples per pot $(n=10)$, per treatment (TE and control), were subjected to ANOVA (MSTAT, 1988).

Expt. 2. Effects of TE on structural carbohydrate content. 'NuStar' KB sod was harvested from the field and established in four 75 $\times 110-\mathrm{cm}$ wooden flats over $15 \mathrm{~cm}$ of Nunn clay loam soil (fine montmorillonitic mesic Aridic Argiustoll, $\mathrm{pH}=7.8$ ) on 20 Nov. 1996. The four flats were each split down the middle so that there were eight experimental units of $0.21 \mathrm{~m}^{2}$ randomly arranged in four blocks on the greenhouse bench. Greenhouse conditions, watering, fertilizing, and mowing procedures were as described for Expt. 1. Following establishment, TE was applied $\left(0.27 \mathrm{~kg} \cdot \mathrm{ha}^{-1}\right.$ a.i. $)$ as described for Expt. 1 to half of the experimental units on 20 Jan. 1997. On 5 Feb. (2 WAT) and 19 Feb. ( 4 WAT), $\approx 40 \mathrm{~g}$ of leaf tissue (fresh weight) was clipped from each unit, placed in a paper bag, and dried in a forced-air oven at $70{ }^{\circ} \mathrm{C}$ for $24 \mathrm{~h}$. Tissue samples were then ground in a Udy Cyclone Sample Mill (Udy Corp., Fort Collins, Colo.) through a $1.0-\mathrm{mm}$ screen. Structural carbohydrate concentrations were estimated by the neutral detergent fiber (NDF) procedure of Goering and Van Soest (1970). Plants were again sprayed with $0.27 \mathrm{~kg} \cdot \mathrm{ha}^{-1}$ a.i. TE on 19 Feb., and 40-g leaf tissue samples were collected and processed as before at 2 and 4 WAT. An ANOVA was performed on the NDF results (MSTAT, 1988).

\section{Results and Discussion}

Expt. 1. Effects of TE on cell density and cholrophyll concentration. Trinexapac-ethyl increased mesophyll cell density at 4 WAT, while cell length was reduced (Table 1). No changes in cell width were noted. Differences in cell density and length in treated and untreated plants are apparent in Fig. 1. These anatomical changes are similar to those reported in gibberellin-deficient wheat (LeCain et al., 1989).
Total chlorophyll concentration of leaf blade tissue was increased by TE at 2 , but not at 4 WAT (Table 1). Increased cell density and chlorophyll concentration were correlated with greater carbon dioxide exchange rates for single leaves of gibberellin-deficient wheat (Morgan et al., 1990). Chlorophyll $b$ concentrations had increased at 2 and 4 WAT, while chlorophyll $a$ concentrations were unaffected at 2 WAT, but were reduced by TE at 4 WAT (Table 1 ). Shade-adapted leaves have higher chlorophyll $b$ levels because chloroplasts contain more grana, increasing the efficiency of light energy capture (Salisbury and Ross, 1992). The KB used for chlorophyll determinations in this study was grown in a shaded greenhouse under $\approx 46 \%$ of full sun. Trinexapac-ethyl and another GA-inhibitor, flurprimidol $\{\alpha-(1-$ methylethyl)- $\alpha$-[(trifluoromethoxy)phenyl]-5pyrimidinemethanol $\}$, reportedly increase the shade tolerance of Zoysia matrella (L.) Merr. and KB, respectively (Qian and Engelke, 1999;
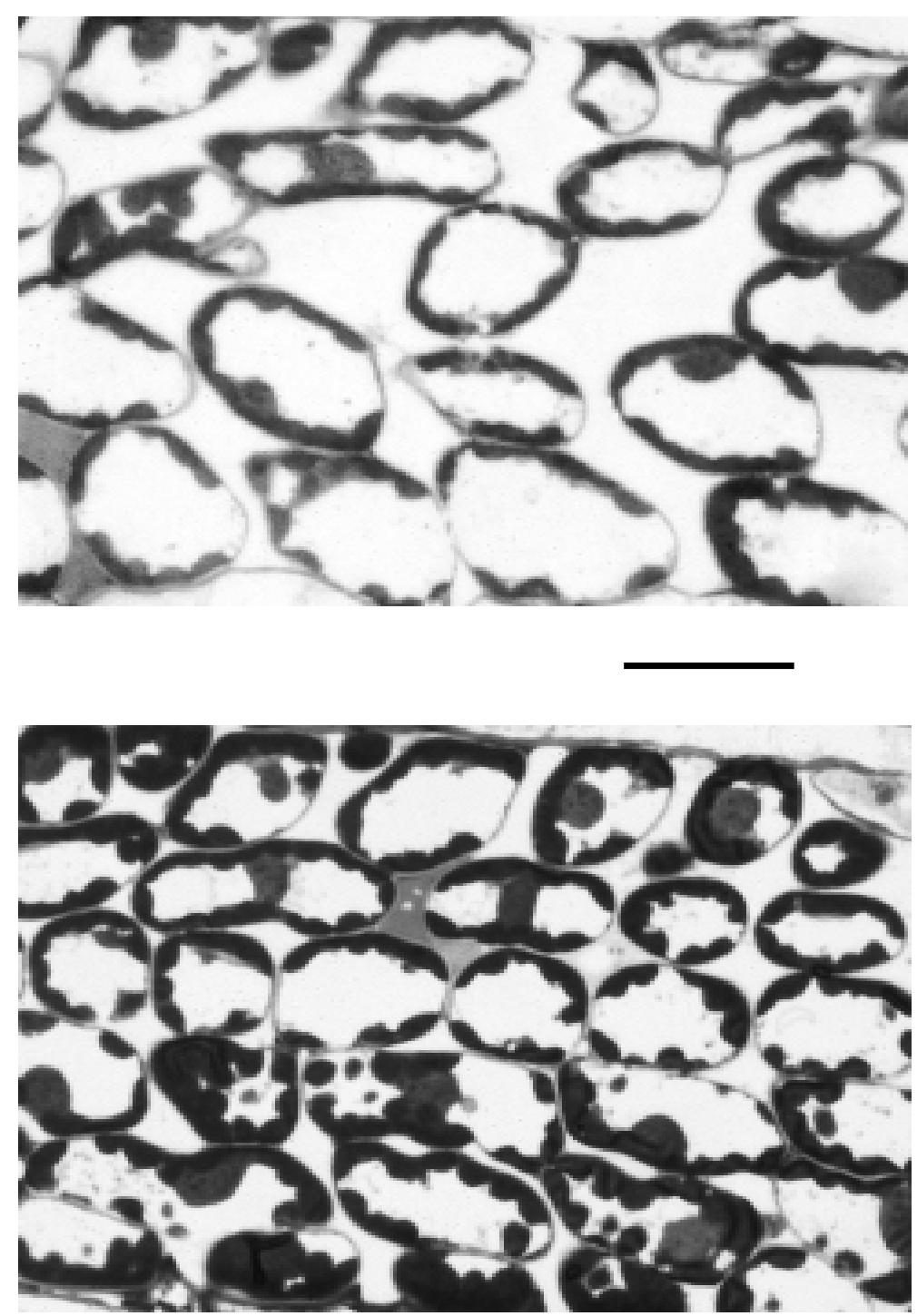

Fig. 1. Representative longitudinal sections ( $\times 100$ magnification $)$ from (top) an untreated 'NuStar' Kentucky bluegrass leaf blade showing loosely packed and larger mesophyll cells, and (bottom) a trinexapac-ethyl treated leaf blade showing tightly packed and smaller mesophyll cells. Bar represents $50 \mu \mathrm{m}$. 
Table 1: Effects of trinexapac-ethyl (TE) (0.27 $\mathrm{kg} \cdot \mathrm{ha}^{-1}$ (a.i.) on mesophyll cells and chlorophyll concentration of Kentucky bluegrass.

\begin{tabular}{ccccr}
\hline \hline & & & CV \\
Observation & Control & Treated & $P$ & $(\%)$ \\
\hline \multicolumn{5}{c}{ Mesophyll cells $(4 w k)$} \\
No./mm ${ }^{2}$ & 550 & 750 & 0.003 & 22.4 \\
Length $(\mu \mathrm{m})$ & 56 & 45 & 0.001 & 13.5 \\
Width $(\mu \mathrm{m})$ & 32 & 30 & 0.160 & 11.7 \\
Chlorophyll content $\left(m g \cdot g^{-1}\right.$ & $F W)$ & \\
2 WAT - a & 2.71 & 2.94 & 0.170 & 13.0 \\
b & 1.31 & 1.60 & 0.001 & 11.3 \\
Total & 4.02 & 4.55 & 0.004 & 8.4 \\
4 WAT - a & 2.76 & 2.65 & 0.010 & 3.3 \\
b & 0.62 & 1.10 & 0.033 & 53.3 \\
Total & 3.39 & 3.74 & 0.110 & 13.3 \\
\hline
\end{tabular}

Stier et al., 1999). The effects of TE in increasing leaf cell density and chlorophyll $b$ content may increase turfgrass shade tolerance. However, rate of photosynthesis on a single leaf or leaf area basis should be measured on TEtreated turfgrass before any association between these effects and improved shade tolerance can be made.

Expt. 2. Effects of TE on structural carbohydrate content. We posited that increases in leaf blade cell density would be accompanied by increases in the structural carbohydrates that compose leaf blade cell walls. Structural carbohydrate content ranged from 435 to 467 $\mathrm{mg} \cdot \mathrm{g}^{-1}$ dry weight, but no effect of TE was detected, perhaps because structural carbohydrate content was based on leaf weight rather than leaf area. Specific leaf weight (leaf weight/ leaf area) of a semidwarf wheat with antigibberellin genes was greater than that of a tall wheat genotype (Morgan et al., 1990). Although we did not measure specific leaf weight, TE may have reduced the area of leaf sampled for structural carbohydrate content. Thus, no conclusions can be drawn until more detailed studies are conducted to measure TE effects on specific leaf weight and structural carbohy- drate contents on a unit leaf area basis.

In summary, TE reduced cell length, increased mesophyll cell density, total chlorophyll at 2 WAT and chlorophyll $b$ concentrations at 2 and 4 WAT, but did not affect structural carbohydrate content. Its effects on cell density and chlorophyll concentration suggest further research investigating the possible enhancement of leaf blade tensile strength and photosynthetic efficiency by TE.

\section{Literature Cited}

Adams, R., E. Kerber, K. Pfister, and E.W. Weiler. 1992. Studies on the action of the new growth retardant CGA 163'935 (cimectacarb), p. 818827. In: C.M. Karssen, L.C. van Loon, and D. Vreugdenhil (eds.). Progress in plant growth regulation. Kluwer Academic, Dordrecht, The Netherlands.

Arnon, D.I. 1949. Copper enzymes in isolated chloroplasts. Polyphenoloxidases in Beta vulgaris. Plant Physiol. 24:1-15.

Berlyn, G.P. and J.P Miksche. 1976. Botanical microtechnique and cytochemistry. Iowa State Univ. Press, Ames.

Ervin, E.H. and A.J. Koski. 1998. Growth responses of Lolium perenne L. to trinexapac-ethyl. HortScience 33:1200-1202.

Ervin, E.H. and A.J. Koski. 2001. Kentucky bluegrass growth responses to trinexapac-ethyl, traffic, and nitrogen. Crop Sci. (In Press.)

Esau, K. 1953. Plant anatomy. Wiley, New York.

Fagerness, M.J. and D. Penner. 1998. Evaluation of V-10029 and trinexapac-ethyl for annual bluegrass seedhead suppression and growth regulation of five cool-season turfgrass species. Weed Technol. 12:436-440.

Goering, H.K. and P.J. Van Soest. 1970. Forage fiber analysis. U.S. Dept. of Agriculture Handbook no. 379

Grossman, K. 1991. Plant growth retardants: Their mode of action and benefit for physiological research, p. 788-797. In: C.M. Karssen, L.C. van Loon, and D. Vreugdenhil (eds.). Progress in plant growth regulation. Kluwer Academic, Dordrecht, The Netherlands.

Hiscox, J.D. and G.F. Israelstam. 1979. A method for extraction of chlorophyll from leaf tissue without maceration. Can. J. Bot. 57:1332-1334.
Johnson, B.J. 1993. Response of tall fescue to plant growth regulators and mowing frequencies. J. Environ. Hort. 11:163-167.

Johnson, B.J. 1994. Influence of plant growth regulators and mowing on two bermudagrasses. Agron. J. 86:805-810.

Kane, R.T. and R.W. Smiley. 1983. Plant growthregulating effects of systemic fungicides applied to Kentucky bluegrass. Agron. J. 75:469473.

LeCain, D.R., J.A. Morgan, and G. Zerbi. 1989. Leaf anatomy and gas exchange of nearly isogenic semidwarf and tall winter wheat. Crop Sci. 29:1246-1251.

MacAdam, J.W., J.J. Volenec, and C.J. Nelson. 1989. Effects of nitrogen on mesophyll cell division and epidermal cell elongation in tall fescue leaf blades. Plant Physiol. 89:549-556.

Morgan, J.A., D.R. LeCain, and R. Wells. 1990. Semidwarfing genes concentrate photosynthetic machinery and affect leaf gas exchange of wheat. Crop Sci. 30:602-608

MSTAT. 1988. MSTAT-C: A microcomputer program for the design, management, and analysis of agronomic research experiments. MSTAT/ Crop and Soil Sciences Dept., Michigan State Univ., East Lansing.

Qian, Y.L. and M.C. Engelke. 1999. Influence of trinexapac-ethyl on Diamond zoysiagrass in a shade environment. Crop Sci. 39:202-208.

Salisbury, F.B. and C.W. Ross. 1992. Plant physiology. 4th ed., Wadsworth, Belmont, Calif.

Schnyder, H. and C.J. Nelson. 1988. Diurnal growth of tall fescue leaf blades. Plant Physiol. 86:10701076.

Shearman, R.C. and J.B. Beard. 1975a. Turfgrass wear tolerance mechanisms. II. Effects of cell wall constituents on turfgrass wear tolerance. Agron. J. 67:211-215.

Shearman, R.C. and J.B. Beard. 1975b. Turfgrass wear tolerance mechanisms. III. Physiological, morphological, and anatomical characteristics associated with turfgrass wear tolerance. Agron. J. 67:215-219.

Spurr, A.R. 1969. A low viscocity epoxy resin embedding medium for electron microscopy. J. Ultrastruct. Res. 26:31-43.

Stier, J.C., J.N. Rogers, III, J.R. Crum, and P.E. Rieke. 1999. Flurprimidol effects on Kentucky bluegrass under reduced irradiance. Crop Sci. 39:1423-1430. 